CANADIAN SNOWBIRDS IN MEXICO:

TRANSNATIONAL LIFE EXPERIENCES - A REVERSE PERSPECTIVE

by

Adriana Espinosa de los Monteros Romo, BA, Universidad Autónoma de

Aguascalientes, Mexico, 2006

\author{
A Major Research Paper \\ presented to Ryerson University \\ in partial fulfillment of the requirements for the degree of \\ Master of Arts \\ in the program of \\ Immigration and Settlement Studies
}

Toronto, Ontario, Canada, 2018

(C) Adriana Espinosa de los Monteros Romo, 2018 


\section{AUTHOR'S DECLARATION FOR ELECTRONIC SUBMISSION OF A MRP}

I hereby declare that I am the sole author of this MRP. This is a true copy of the MRP, including any required final revisions.

I authorize Ryerson University to lend this MRP to other institutions or individuals for the purpose of scholarly research.

I further authorize Ryerson University to reproduce this MRP by photocopying or by other means, in total or in part, at the request of other institutions or individuals for the purpose of scholarly research.

I understand that my MRP may be made electronically available to the public.

Adriana Espinosa de los Monteros Romo 


\title{
CANADIAN SNOWBIRDS IN MEXICO: \\ TRANSNATIONAL LIFE EXPERIENCES - A REVERSE PERSPECTIVE
}

\author{
Adriana Espinosa de los Monteros Romo \\ Master of Arts, 2018 \\ Immigration and Settlement Studies \\ Ryerson University
}

\begin{abstract}
Much has been said of migrants coming from all over the world to Canada, but there is a rarely interest in the other side of the fence. Every year thousands of Canadians escape from the cold weather during winter season, they are the so-called snowbirds. This paper portrays the life experiences of seven Canadian snowbirds who shared the journey of spending three to seven months each year in five different cities in Mexico. Through the lens of transnationalism, this paper sheds light on a better understanding of this growing phenomenon. It explains how this seasonal migration has developed transnational behaviours in the life of the snowbirds; reflected in their mobility, identity, social networks, political awareness, as well as their cultural and economic practices. This study is not focusing on a specific community but rather on the broader phenomenon across Mexico given Canadian snowbirds are not a homogeneous diaspora in Mexico.
\end{abstract}

Keywords: Canadian snowbirds, Mexico, transnationalism, seasonal migration. 


\section{ACKNOWLEDGEMENTS}

I am very grateful to my supervisor, Dr. Colin Mooers, and my second reader, Dr. Myer Siemiatycki for their support, their encouragement and for believing in this project against all the odds. This major research paper would not have been possible without their knowledge, patience and wisdom.

A very special gratitude goes to my research participants: Marnie, John, Phoebe, Sharon, Sue, Trudy and Michael. Thank you for sharing your life journey in Mexico, your stories are the core of this project that would not have been possible without your voices.

Thank you, Lidia and Berti, for being my "Latino power", for always being there and encourage me to not give up to this dream. Thank you to the "gals": Riley, Amelia, Eva, Lorelle, Sinthu, and Rachel for your kind words and love. Thanks, Aidan, who gave me guidance on how to write my very first essay and listened to me when I needed it. I remember the very first days at this program, after so many years, in a different country, in a different language when I was about to drop the program but I did not do it thanks to my amazing friends and program peers who were my strength to continue in this path. This cohort is definitely the best!

I am immensely grateful to my colleagues and friends at York University, Dr. Valerie Preston, Dr. Anneke Rummens, Naolo Charles, Sabrina Rajpaul, Camila Bonifaz and Dr. Marshia Akbar, for providing me with the so much needed resilience.

Thank you to Emily, Sarah, Marce and Dr. Barlas, I could have never made it without their professionalism and their kindness.

Also, I want to express my gratitude to the program director, Dr. Harald Bauder, who was always very supportive, especially during the difficult moments I passed through in this program.

To all and each one of you, thank you a lot. 


\section{DEDICATORIA}

A Val, mi musa, por siempre creer en mí, por ser mi fuerza, mi luz, mi razón. Por alentarme a buscar nuevos retos y nunca desistir. Por inspirarme a querer ser una mejor persona y por iluminar mi camino siempre con tu sonrisa.

A ti mamá, por impulsarme a ser mejor, a no darme por vencida y motivarme a demostrar al mundo lo lejos que puedo llegar, si lucho por ello.

A papá, por inculcarme el amor por los libros y el conocimiento.

A Mony, guerrera incansable y mi ejemplo a seguir. Por transmitirme tu fuerza y coraje ante cualquier circunstancia que la vida te ha puesto enfrente.

A Sergio, mi hermanito, por tus palabras de aliento, por aquel "no te rindas" cuando más lo necesitaba, por estar ahí siempre, atento y comprensivo cuando sentía que no podía más.

A Santi y Sofi porque, sin saberlo, me dieron la fuerza para lograr este reto pues quiero que estén orgullosos de su tía.

A mis hermanos elegidos, mis amigos, que siempre han estado ahí, apoyándome sin importar nada más que el cariño que nos une. Ustedes me han dado fuerza con su apoyo incondicional.

Gracias a todos por su amor que me ayudó a lograr este sueño. 


\section{TABLE OF CONTENTS}

Author's declaration ii

Abstract iii

Acknowledgements iv

Dedicatoria $v$

$\begin{array}{ll}\text { INTRODUCTION } & 1\end{array}$

CHAPTER ONE: LITERATURE REVIEW

Snowbirds: seasonal migrants or long-term tourists?

$\begin{array}{ll}\text { Characteristics of the snowbirds } & 10\end{array}$

Canadian snowbirds in Mexico: a paradise beyond the American Sunbelt

CHAPTER TWO: THEORETICAL FRAMEWORK

$\begin{array}{ll}\text { Transnational life experiences } & 17\end{array}$

Gustafson: six dimensions of transnationalism 19

CHAPTER THREE: METHODOLOGY

An exploratory study of Canadian snowbirds in Mexico 23

CHAPTER FOUR: FINDINGS AND DISCUSSION

Canadian snowbirds in Mexico: Transnational Life Experiences 27

$\begin{array}{ll}\text { Not everyone likes to be a snowbird } & 27\end{array}$

Cold ageing, warm youth 36

$\begin{array}{ll}\text { Exotic but familiar } & 40\end{array}$

Do you speak Spanish? -Un poquito 45

Where is home?

CONCLUDING REMARKS

$\begin{array}{ll}\text { References } & 61\end{array}$ 


\section{INTRODUCTION}

Back in 2013, I discovered a little beach town in the Mexican Caribbean, Paamul, located in the state of Quintana Roo. This community is characterized by having more than one hundred recreational vehicles (RVs) by the sea where retired people, from Canada and the U.S. mostly, live from October to April. Some of the RVs are placed under huge palapas ${ }^{1}$; some others have a small lovely backyard perfectly designed with colourful flowers. Winters there feel full of life and energy, and a positive vibe is on the air. In contrast, during the summertime, the very same place feels cold, given the fact that it is isolated, and even if the heat and the humidity are at their highest levels; it looks like a ghost town. That was the time when my research began: if not in a formal manner but out of curiosity, I started gathering information on websites and magazines. I discovered that Paamul was not the only place in Mexico where this happens and that thousands of Canadians make their trip down to the country every winter, as the monarch butterflies do; and like them, they return to their homeland in the springtime. They are well known as snowbirds.

Migration studies usually have paid more attention to the flows of people moving East-West or South-North. Little interest is taken in those moving NorthSouth whose primary purpose of travel is neither working nor an escape from wars, political or poor economic conditions; usually, they are not racialized nor do they struggle finding jobs (Benson \& O’Reilly, 2009; Lizárraga, Mantecón, \& Huete, 2015). In regards to the binary formula, Canada and migration, most of the research has focused on Canada as a receiving country, overlooking it as a

\footnotetext{
1 "A traditional Mexican shelter roofed with palm leaves or branches" (Oxford dictionaries, n.d.)
} 
sending country (Hayes, 2015). However, a two-sided study is necessary to have a view of the whole picture.

Migration, defined by Smith and House (2006), is "the change in one's place of usual residence" (p. 232). This change does not only refer to the movements made to (im)migrate permanently to another country, as it is commonly assumed in classical models of migration (Witter, Cela \& Fokkema, 2015). Indeed, GlickSchiller et al. (1995) suggest that migration is more than one permanent move from the original place of residence but instead, an "ongoing process" (as cited in Lizárraga et al., 2015, p. 140). Under that premise, all other shorter trips or "seasonal shifts", made by those who are not (im)migrants struggling to assimilate in a new country or to find a job, constitute another type of migration to which Smith and House refer as "temporary migration" (2006, p. 232).

The long-term temporary migration of Canadian snowbirds in Mexico is a growing, under-researched phenomenon in the migration field given that it has mostly focused on Canadians in the American Sunbelt ${ }^{2}$ (Desrosiers-Lauzon, 2011; Bjelde \& Sanders, 2012; Smith \& House, 2006; Longino, Marshall, Mullins, \& Tucker, 1991; Happel \& Hogan, 2002). According to Northcott and Petruik (2011), "apparently, the seasonal migration of elderly Canadian snowbirds to southern destinations remains a greatly underestimated and understudied phenomenon" ( $p$. 317). Despite the fact that some interest has emerged about this theme, Gustafson affirms, "little attention has been given to the migrants' experiences of mobility, to their dual and sometimes multiple place attachment, and to their strategies for

\footnotetext{
${ }^{2}$ Term used to refer to the Southern strip of the US, that crosses from East to West (Florida to California). This region is known for its sunny and warm climate and for receiving, since the 1960s, a high number of retired people, who come from Northern regions, escaping from the cold winters.
} 
managing cultural differences between their home countries and the countries to which they migrate" (Gustafson, 2001, p. 373). Therefore, there is a gap in the research that needs to be addressed.

The objective of this paper is to attempt to fill some of this gap. I want to answer some questions such as: Who are the snowbirds? Are they only escaping from the winter? What did they find in Mexico that made them return every year? What transnational ties have they built as a result of this experience? Do they become part of local communities or keep their ties to Canada? The previous questions are to be answered by the snowbirds themselves through in-depth, semistructured interviews conducted with seven people who "fit" into the category of snowbirds according to the definition provided by Happel and Hogan (2006), and Hogan \& Steinnes (1993), and who were living in Mexico at least three to four months per year in the last 3 years. In order to answer the above questions and to analyze the life experiences of the Canadian snowbirds in Mexico, I have organized this paper into four chapters and a concluding remarks section.

In the first chapter, I will make a broad survey of the literature about snowbirds in general; I will then provide the available information about snowbirds in Mexico specifically. In the second chapter, I will briefly explain some transnational theories and explore Gustafson's (2008) analytical dimensions of transnationalism that will be used as the main lense of analysis of this research. In the third chapter, I will explain the method used to conduct this research. In the fourth chapter, I will present the findings that emerged from the interviews and discuss them. Finally, I will provide concluding thoughts resulting from the work performed in this research. 
This is the first study of its kind as there is no research looking into the lived experiences of Canadian snowbirds in Mexico. It is a first attempt to study them at a micro level, to hear their voices, and to analyze a new perspective of the phenomenon: the human one. It is necessary to add that this is not a case study of a specific community but an analysis of the broader phenomenon across Mexico, given that Canadian snowbirds are not a homogeneous diaspora in Mexico. 


\section{Chapter 1}

\section{LITERATURE REVIEW}

\section{Snowbirds: seasonal migrants or long-term tourists?}

The term snowbird has evolved since its emergence. At the beginning of the 20th century, "snowbird" referred to the men who enlisted in the army to get food, clothing and avoid the harsh winters in the North, and then with the arrival of the spring they resigned (Merriam-Webster, n.d.). Later in the 1920s, the concept was used to refer to the migrant labourers who could not stand the cold weather and headed south seeking refuge. As of the 1960s, this name was used for the temporary migrants travelling to Miami and its surroundings, usually for leisure purposes, to avoid cold winters (Desrosiers-Lauzon, 2011). The definition provided by Hogan and Steinnes also refers to Florida; they pointed out that snowbirds are "northern residents who spend part of the winter in the Sunbelt" (1993, p. 246). In recent years, it is not only used to refer to those going to Miami but also to other destinations except for Australia where they are named grey nomads (Onyx \& Leonard, 2005). Coates, Healy and Morrison (2002) define them as "warmthseeking seasonal migrants" (p.433) who escape from the cold weather during the winter season, fleeing from the extreme cold, from snow shovelling and the short and dark days. Finally, Happel, Hogan \& Choi not only refer to the climate but also to the age and occupation, defining snowbird as "a retired/semi-retired individual 55 and older who stays at the seasonal residence one month" $(2004$, p. 5). This study focuses only on those who spent more than three months in Mexico to ensure they were not only having a long vacation but, in fact, establishing themselves (even for relatively short time) for some months in Mexico. 
Navigating the research about snowbirds has not been an easy endeavour. Scholars have not arrived at a consensus of whether snowbirds are long-term tourists or visitors (Rodríguez Chávez \& Cobo Quintero, 2017), seasonal or temporary residents (Longino et al., 1991; Smith \& House, 2006), or seasonal migrants (Coates et al., 2002; Northcott \& Petruik, 2011; Edmonston \& Lee, 2014). Other scholars as Bantman-Masum (2015) do not enter in the discussions above, referring to them only as the well-known group of people who move to warmer climates during the winter. In an attempt to clarify the grey area to determine what type of migration snowbirds perform, it is useful to review O'Reilly's (1995) five-fold typology that includes time spent and intention of stay in a country different from the one of the usual residence:

Expatriates: moved permanently; identify as living in the area; might own property; express intention of never returning.

Residents: residents in terms of home, orientation and legal status, but spend 2-5 months a year in the country of origin where they either own second homes or visit friends and family.

Seasonal visitors: live in the country of origin, but return to the destination for 2-6 months each year, in one or more trips; orientated to the home country.

Returners: usually own second homes; visit irregularly depending on commitments.

Tourists: identified as being in the area specifically for a holiday. Some may own apartments, but most rent space for a short duration (as cited in Williams, King, Warnes, A., \& Patterson, 2000, p. 36-37). 
Given the above, snowbirds fall under the seasonal visitors' classification as they keep their formal residence in the country of origin but spend 2-6 months of the year in the country of destination. Furthermore, O'Reilly's typology leads us to the debate about the difference between expatriates and immigrants. Croucher (2012) suggests that amongst all different movements of people, there is a group of relatively wealthier and privileged ones whose migration flows are not driven by the hardship in their country of origin but by the search of a better quality of life. When members of that group of migrants decide to establish themselves in developing countries, they are rather called expatriates rather than immigrants. Croucher explains that this difference lies in economic privilege; push factors driving these migrants are not related to an economic lack but rather an improvement in their ways of living. While in the public realm, immigrants are usually related to adversity, "powerlessness, minority status, and often colour" (O'Reilly, 2000; as cited in Croucher, 2012, p. 4); I would argue, that even though snowbirds do not have to face discrimination nor do they pass through economic struggles, they are still lacking "something" in their lives. This lack can be a social, an environmental or a personal absence. Snowbirds are still moving looking for something they could not find in their country of origin. After they broke their permanency in Canada, and began the back and forth migration to Mexico, they started to satisfy that, sometimes, imperceptible need.

As indicated by Croucher (2012) a lack of accurate terminology has limited the focus of the research. A precise definition of snowbird would allow a betterorganized study of the topic beyond the current overlap amongst different fields of study that go from migration to sociology, gerontology and psychology. Usually, the 
existing research studies do not focus specifically on snowbirds but rather on categories of analysis such as aging and retirement (Schweppe \& Horn, 2015; Balkir \& Böcker, 2015; Witter, Cela, \& Fokkema, 2015); leisure or lifestyle (Bantman-Masum, 2013, Casado-Diaz, 2012); privileged migration (Benson \& O'Reilly, 2009; Croucher, 2012); determinants of their mobility (Edmonston \& Lee, 2014); and migration patterns (Coates, Healy, \& Morrison, 2002; Longino et al., 1991). Therefore, scholars have made their analysis —of different dimensions, with approaches and in different fields of study - focusing on different groups of people, who decided to move to a different country on a temporary or permanent basis at their retirement or pre-retirement age, rather than on snowbirds.

In terms of geographies, analysis of snowbirds has been done in the American continent (Coates, Healy \& Morrison, 2002; Bjelde \& Sanders, 2012; Bantman-Masum, 2013, 2015; Northcott \& Petruik, 2011; Rodriguez \& Cobo, 2012, 2017; Desrosiers-Lauzon, 2011), in Europe (Williams et al., 2000; Bolzman, Fibbi, \& Vial 2006; Horn and Schweppe, 2015; Balkir \& Böcker, 2015; Witter, Cela, \& Fokkema, 2015) and Oceania (Onyx \& Leonard, 2005; Mings, 1997). The interest of studying the phenomenon in different localities indicates an increase in the occurrence of these movements around the world. This is continuously attributed to baby boomers who according to Coates et al. (2002) are "the world's wealthiest generation ever" (p. 448) and are reaching the age of retirement and have the means to migrate to the South to find better climates and lifestyles. In contrast, Bradley and Longino (2009) argue that the last generations of baby boomers will probably not be wealthy enough to move to Southern locations nor have the need 
to follow the same migration pattern, because usual places of residence are becoming more senior friendly (as cited in Northcott \& Petruik, 2011).

Finally, Desrosiers-Lauzon (2011) condenses the previous debates stating that snowbirds fall within the above categories. This is not only because of the length of stay or activities they perform in the host country but also given the complexity of their developed identities. In his book Florida's Snowbirds, he states:

They are tourists because they are sightseers, they are visitors because they interact with Florida and Floridians, they are migrants because they settle in the state, and are seen as outsiders; yet they are residents because they elect to live in dwellings officially defined as permanent residences albeit in a unique, semi-permanent fashion. Finally, snowbirds are community builders, through their unique lifestyle — leisurely but not quite like tourists, with homeownership but unlike permanent residents - and their practice of sociability and mutual help (2011, p. ix-x).

That being said, the term snowbird is not well defined yet. Their mobility is a response to satisfy different needs, desires and a dearth of social, cultural or economic advantages that their country cannot offer them. In that continuous search, snowbirds are somewhat compelled to always live in that "in-betweenness" clearly explained by Desrosiers-Lauzon:

They have always been living at the boundaries of different cultures and folkways, at the juncture between accommodations and housing, leisure and workday routine, North and South. Looking at snowbirds sheds light not only on Florida but also on their homelands as well as the links and divergences between them (2011, p. x). 
Looking at the snowbirds is to see a two-sided mirror to the past and the future, to youth and age, to the permanent and the ephemeral.

\section{Characteristics of the snowbirds}

The shared characteristics of the snowbirds were found by different scholars such as Fulman, 2000; McHugh \& Mings, 1996; Smith \& House, 2006, who concluded that most of them were baby boomers who started migrating temporarily because they were highly educated and used to travel for work and leisure purposes; some have enough retirement income to travel and reside in another country; they have a longer life expectancy; and technology and communications allow them to be in touch with their family and friends while they are away (as cited in Bjelde \& Sanders, 2012). Also, according to Statistics Canada projections, people aged 65 years or older will make up $25.5 \%$ of the total population by 2061 ; these people are generally retired, and as a natural result their lifestyle changes with retirement; they contemplate migration as they don't feel any attachment to their work or to a specific area of residence (as cited in Edmonston \& Lee, 2014).

Other characteristics that distinguish this group is that they have a lot of flexibility and adaptability to changes, they get to know new people and create friendships but also maintain their old ones in their hometowns (Bjelde \& Sanders, 2012). In regards to demographics, their mobility is higher in their late 60 s or early 70s; males are more likely to live this kind of temporary migration; single, divorced, separated or widowed people tend to immigrate in higher percentages that married people (Edmonston \& Lee, 2014).

Moreover, the type of migration made by snowbirds falls under the category of what Bantman-Masum (2013) defines as "lifestyle migration" (p. 87). This 
migration refers to people from developed countries, who move temporarily or permanently to more pleasant ${ }^{3}$ developing countries, to take advantage of their economy that benefits them, resulting in a more comfortable lifestyle that they probably would not be able to afford in their countries of origin. Also, the "back and forth" type of migration of the snowbirds fits into what McHugh and Ming (1996) call "circular life-course trajectory and place attachment" (as cited in Bjelde and Sanders, 2012, p. 329), meaning that they will travel and reside for a certain period in a second country, always returning to their "rooted home place" (p. 329). This type of migration is also explained by Balkir and Böcker (2015), who analyzed the returning patterns of Northern Europeans. They would spend the winters in warmer countries like Spain, always returning to their "usual" place of residence in spring or summer. The authors called this migration "pendular" (p. 127). Beyond some of the differences in how scholars describe snowbirds' flows, Coates et al. highlighted what they all have in common, "like their avian counterparts, they return on a regular basis" (2002, p. 439).

Due to all of the above, it can be said that snowbirds are generally retired people, relatively privileged, given that they can afford to spend winters in warmer countries with cheaper costs of living that allow them to have a better lifestyle. Snowbirds are flexible and easily adapt to new communities of people with ethnic, cultural or social affinities that make them feel at home away from their usual place of residence. Such communities and previous travel experiences, in the chosen country or region, encourage them to return year after year to the same places. Moreover, these temporary places of residence have all the resources that permit

\footnotetext{
${ }^{3}$ Warm weather, cheap and high quality services, less stressful cities or towns.
} 
them to maintain the same or better quality of life and keep contact with their families. Finally, more extended stays in the host country are developmental and planned, meaning that they result from previous and continuous touristic trips, facilitating the decision to return every year for longer periods of time.

\section{Canadian snowbirds in Mexico: a paradise beyond the American Sunbelt}

Coates et al. (2002) highlight the fact that seasonal migration to Mexico is becoming more and more attractive to Canadian snowbirds due to the increase of costs of living and vacationing in the U.S. They also suggest that the baby boom generation reached their retirement age at the beginning of the 2000 s and started moving temporarily or permanently to the South (Mexico). They add that given the economic circumstances at the beginning of the $21^{\text {st }}$ century, these migrations are not performed only by Canadians and Americans with high socioeconomic status only, but also by people with middle and lower incomes.

Furthermore, Mexico is not known for being a country that is substantially open to immigration. Its nationalist migratory policy was established some years ago after the end of the Mexican revolution in the 1930s, and its goal was the growth and development of the country from the inside and not through immigration (Rodríguez Chávez \& Cobo Quintero, 2017). Notwithstanding, this policy welcomed investors, executives and professionals who were the first migrants who arrived in Mexico from Canada to invest and work in mining and transportation companies (Rodriguez \& Cobo, 2012).

According to Rodriguez and Cobo (2012), the first groups of Canadian retirees began coming down to the coasts of Mexico in the 1980s. Records of the first Canadian snowbirds in Mexico date back to the 1990s when their migration 
expanded further from the American Sunbelt region as they realized the weather was warmer and the cost of living was much cheaper in Mexico than in the U.S.; furthermore, immigration policies have been eased (Rodriguez \& Cobo, 2012; 2017; Coates et al., 2002). Moreover the enactment of the North American Trade Free Agreement (NAFTA) in 1994 increased not only commerce and investment, but also enabled the movement of people (especially from North to South). Mexican immigration policy became more flexible given the political and economic conditions at the time, easing the temporary flow of tourists into the country, as this sector represents a significant economic asset to the country (Rodríguez Chávez \& Cobo Quintero, 2017).

In 1999, Everitt and Welsted stated: "Mexico has become not only an increasingly important tourist destination but also a winter target for Canadian "snowbirds'" (p. 179). In recent years, according to the Canadian Embassy in Mexico (2017), Mexico is one of the top sun travel destinations for Canadians, ranked in second place just behind the U.S. Mexico receives annually 1.9 million Canadian tourists and it is stated that "tens of thousands are estimated to be snowbirds" (Government of Canada, 2017). Rodríguez Chávez and Cobo Quintero (2017) gathered information from a 2014 OECD report showing that Canadians are the $8^{\text {th }}$ group of foreigners residing in Mexico. It is difficult to estimate an accurate number of snowbirds in Mexico, as some of them choose to acquire a permanent resident status (even if they do not live the full year in Mexico), while some others do not apply for permanent residence due to the fear of losing benefits in Canada, thus their status remains as temporary. Also, it is difficult to track snowbirds in the 
census, because they might not be in the country when the census is carried as highlighted by Rodriguez Chávez and Cobo Quintero (2017).

While there is no formal research on the reasons that attract Canadian snowbirds to Mexico, this study is similar to the research project conducted by Lardiés-Bosque, Guillén, and Montes-de-Oca (2016) about retired Americans in Mexico. Lardiés-Bosque and his colleagues found out that amongst the drivers that boosted migratory flows of Americans to Mexico were "improved quality of life, better climate, geographical proximity, accessibility to amenities and pastimes, previous tourism experiences in the country, and economic opportunities -lower prices - linked to the availability of inexpensive medical treatment, medicines and housing" (p. 818). Furthermore, Coates et al. (2002) explained that it is common that before relocating to Mexico for retirement, the majority of American retirees vacationed there, developing different forms of temporary and permanent residential mobility between both countries (as cited in Lardiés-Bosque et al., 2016, p 818). These factors can also fit the needs and possible causes of the migration of Canadian snowbirds to Mexico, given that they share most of the characteristics describing the Americans and their reasons to migrate to Mexico.

Moreover, some of the possible reasons for Canadian snowbirds to migrate temporarily to Mexico could be weather, health care, cost of living, and sociocultural factors. The weather is one of the main driving forces to leave Canada given the harsh winter temperatures in Canada. Furthermore, health care can be both a push and a pull factor since all provinces require a minimum stay in the country to qualify for medical services (Government of Ontario, 2017; Gouvernement du Québec, 2016; Province of British Columbia, 2017; Government 
of Alberta, 2017; Province of Manitoba, 2017). In addition, the cost of living in Mexico is cheaper than in Canada and the U.S. In the last five years, the Canadian dollar was on downward trend compared to the U.S. dollar. In contrast, the Canadian dollar has remained steady or even gained in value against the Mexican peso (OFX, 2017). Regarding the socio-cultural factors, Rodríguez Chávez and Cobo Quintero (2017) found that the constant return of Canadians to the same communities, where they organize annual local activities, has allowed them to interact with locals resulting in an enriching cultural and social exchange that benefits both communities, the local and the Canadian.

According to the research on Canadians in Mexico made by Rodríguez Chávez and Cobo Quintero (2017), the leading travel destinations in Mexico for retired Canadians and snowbirds include beach cities and towns in the Pacific coast such as Puerto Vallarta, Bahía de Banderas and Compostela; in Quintana Roo, Cancun and Playa del Carmen; and colonial, urbanized towns like San Miguel de Allende. Also, in Cahnmann-Taylor's (2014) study about adults studying Spanish in Mexico, she pointed out that Oaxaca attracts snowbirds not only to study the language but also because of its "cultural and artistic complexity, relative safety, near-perfect climate [...]" (p. 409). Therefore, as stated by Lizárraga et al. (2015), different geographies attract different type of people. This is the case of this study, where 7 Canadian snowbirds migrate to 5 very different cities in Mexico.

Despite the fact that there is research about snowbirds across the world, I found only five studies about Canadians in Mexico. Some of these talk about snowbirds in some sections, but they are not entirely focused on them (Bantman- 
Masum, 2013; Everitt \& Welsted, 1999; Rodriguez Chavez \& Cobo Quintero, 2012, 2017). Only one of the research projects delved into Canadian (and American) snowbirds in Mexico (Coates et al., 2002). It can be therefore reiterated that there is a need for specific research focused on Canadian snowbirds in Mexico. 


\section{Chapter 2}

\section{THEORETICAL FRAMEWORK}

\section{Transnational Life Experiences}

In the globalized world where we all have been living in the last few decades, different groups of people are linking their lives and interacting with persons not only from their homelands but also beyond borders and nation-states (Satzewich \& Wong, 2011). Portes, Guarnizo and Landolt (1999) pointed out that casual trips and the activities of communities of expatriates are not considered transnational even when they strengthen transnationalism on the ground. However, Faist (2000) provides a more straightforward definition of transnationalism: "ties and the unfolding strong and dense circular flows of persons, goods, ideas, and symbols within a migration system" (as cited in Satzewich \& Wong, 2011, p. 5). The emergence of transnational studies changed the perspective of the study of migratory movements because they will no longer be studied from one perspective point. Transnationalism assumes multiples affiliations to different localities and moves away from the idea of studying migration only at the place of origin or the new place of residence (Vertovec, 2001).

However, when talking about transnationalism, there is also the assumption, shared with migration studies in general, that a change of residence to a new country is going to be permanent. Basch, Glick Schiller and Szanton-Blanc (1994); Glick Schiller (2000); and Guarnizo (1994), in their "linear transnationalism", explained that one of the possible causes for the development of transnational ties is the need of migrants to maintain ties with their family and friends "in the country they left behind" (as cited in Itzigsohn \& Saucedo, 2002, p. 771), suggesting that 
migrants are in the new country permanently. Another assumption is that pendular migration flows are West-East, South-South or South-North as stated by De Wenden (2009) while explaining the new migration tendencies. In contrast, Gustafson (2008) suggests that migration is not a single permanent movement but an ongoing process that involves repeated movements between the country of origin and the host country. Similarly, studies on transnational ageing are prevalent amongst the research related to snowbirds since one of the characteristics of the snowbirds is that they are at the age of retirement. Transnational ageing then, as stated by Horn and Schweppe, is "the process of organizing, shaping, and coping with life in old age in contexts which are no longer limited to the frame of a single nation-state" (2015, p. 7). Research studies about transnational ageing touch on topics related to snowbirds, underscoring how their dual residences and pendular migrations make them develop transnational behaviours and ties to sending and receiving countries (Witter et al., 2015; Balkir \& Böcker, 2015).

Similarly to classical migration studies, scholars such Portes, Rumbaut, Handlin, Guarnizo, Landolt, Levitt among others (as cited in Croucher, 2009, 2012) have studied transnationalism from the perspective of migrants in hardship conditions looking for better economic opportunities, usually emigrating from Southern countries in Latin America to the United States. In contrast, Croucher (2009) has paid more attention to the transnationalism of relatively privileged migrants in host countries where they can improve their lifestyle. She states: "these studies do not deny power imbalances but explore the implications of reversing the lens to focus on migration from an economically and politically powerful sending 
state to a less powerful receiving one" (p. 465). Croucher calls for further studies of migration from North to South from the transnational perspective.

\section{Gustafson: Six Dimensions of Transnationalism}

The snowbird phenomenon has been studied from different perspectives, approaches and dimensions, as discussed in previous sections. However, this paper aims to analyze the phenomenon through the lens of the six dimensions of transnationalism proposed by Gustafson (2008) in his case study of North European retirees in Spain. The analysis will be made based on these dimensions given that Gustafson recognizes migration as a movement that is not necessarily permanent, as discussed above. Hence, snowbirds' transnational practices can be contextualized in this theoretical model that includes the following dimensions of analysis: mobility, identity and belonging, social networks and social structures, cultural practices and institutions, politics and legislation, and economic activities and exchanges. Each dimension refers to specific practices or behaviours that help to make us understand how people with dual attachments experience transnationalism.

First, Gustafson (2008) suggests that mobility increases transnational ties. This dimension analyses patterns and ideals of mobility portrayed in various travels to sending and receiving countries. Such transnational behaviours are influenced by various factors, for example, developed communication infrastructure, work constraints, and migration policy flexibility, among others. This dimension is pertinent to this study because snowbirds' migration is in continuous mobility, which is the main characteristic that differentiates their migration from all other types of migration with more classic patterns. 
In regards to the second dimension, identity and belonging, Gustafson states, "transnational mobility and transnational connections also raise questions about migrants' sense of home, belonging and identity" (2008, p. 458). This is due to the fact that migrants identify with both the sending and the receiving country at different moments of their migration process. They are now interrelated in two countries, and those that circumstances shape their identities. Also, globalization has boosted multiple belongings to two or several countries simultaneously by the accessibility of international transportation and the development of technology to reach people from all over the world. Moreover, the broad access to information and the media has promoted the empathetic identification with communities located in multiple countries, making easy to develop various belongings (Macklin \& Crépeau, 2010)

In the third dimension, social networks and social structures, Gustafson (2008) explains how social relations in both the sending and receiving country are relevant to develop transnational ties. On the one hand, one of the possible reasons for seasonal migrants to return to their home country is the social connection they have in their country of origin with their family and friends. They maintain these relationships through continuous developing communication technologies. On the other hand, given that snowbirds are away from home, they tend to develop a kinship with people with similar affinities or from the same region either in the receiving country or back at home. Also, they create supportive communities to help each other and local communities.

The fourth dimension, cultural practices and institutions, refers to the flow of cultural practices between the two countries in question and how it has two-sided 
results. On one side, there are different cultural expressions such as book or dancing clubs where migrants develop communities and sometimes mix with locals. On the other side, and mostly when migrants do not speak the local language, this type of activities can isolate them from the local community. The most common cultural practices and institutions, in communities of retirees and similarly with snowbirds, include: social groups, volunteering organizations, culinary experiences, language exchange, media reception and production (Gustafson, 2008). This dimension involves numerous types of manifestations where transnational practices are reproduced.

The fifth dimension, politics and legislation, pertains not only to traditional political participation or activism in either country, but also to everything related to policies and legislation (Gustafson, 2009). Insofar as what concerns this study, it is mostly related with health care and taxation issues. The importance of this dimension lies in its migratory implications and matters like health, which is both a push and a pull factor. Mexico is well known for being a medical tourism country. According to Coates and his colleagues (2002) most Canadians who used private medical services found it cheap and reliable. In contrast, Northcott and Petruik (2011) stated that usually when Canadians have severe health difficulties, they are more inclined to return to Canada rather than stay in the host country. Further, taxation issues can be a driver that might influence the decision of snowbirds as to whether or not to become permanent residents, given that as "tourists" they are in a legal limbo. Therefore, political and legislative matters are relevant to the study of Canadian snowbirds in Mexico. 
The sixth dimension of transnationalism, economic activities and exchanges, refers to all economic transactions performed during the migration process. This not only refers to remittances as in traditional migrations, but also to investments, for example, to own property or run a business in one or both countries. Fundraising and all kinds of economic activities resulting from their flows between countries are encompassed in this dimension. In fact, North-South migrants are a significant market for local businesses (Gustafson, 2008). In Mexico, according to Schafran and Monkkonen (2011), who performed a study of American snowbirds, large communities of retirees can be found in San Miguel de Allende because of its urban infrastructure that allows them to integrate easily. This town offers a variety of venues for cultural and social recreation: theatres, galleries, restaurants and malls. This infrastructure boosts the local economy and still benefits Canadians given the beneficial exchange rate of the Canadian dollar against the Mexican peso.

In view of the foregoing, the analysis in the upcoming sections relies on Gustafson's transnational dimensions, attempting to understand the different life experiences of Canadian snowbirds through their transnational behaviours. 


\section{Chapter 3}

\section{An Exploratory Study of Canadian Snowbirds in Mexico}

In order to explore the themes that emerged from the literature review, I conducted exploratory qualitative research that uses a mixed interpretive and, phenomenological narrative approach. Through the review of the existing research and through interviews with snowbirds, I look to provide a general overview of the lived experiences of the Canadian snowbirds in Mexico. This study will allow the creation of "new ideas, conjectures, or hypotheses that determine the feasibility of conducting future research" (Neuman \& Robson, 2018, p. 11-12). Through the interpretive approach, I am trying to gain an "empathetic understanding" (Neuman \& Robson, 2018, p. 29) about the seasonal migration of the snowbird, allowing me to know their perspectives. I used a phenomenological approach to find the shared meaning of the experience of the Canadian snowbirds interviewed and to analyze similarities in their experiences and the construction of their identity and sense of community. The study also has a narrative approach (Neuman \& Robson, 2018) given that it tells the stories of the participants' everyday lives in Mexico so that, through this paper, they can see the portrait of their lives and those of their counterparts in different cities across the country.

I conducted seven semi-structured interviews; this is the most commonly used method in qualitative research (Harper, 2011). In addition, it allows for an indepth understanding of a social phenomenon (Neuman \& Robson, 2018) and, therefore, the "snowbird experience" can be better comprehended. The focus of the interviews was to have a grounded understanding of the experience of the Canadian snowbirds in Mexico and to give voice to their interpretation of the 
phenomenon (Bryman, Bell \& Teevan, 2012). Participants were recruited through snowball sampling (Neuman \& Robson, 2018). I had a previous connection with some snowbirds or people who knew snowbirds to whom I sent recruitment emails. Initially, I was going to interview 3 to 5 people; however, given the high response to the recruitment, I chose to interview 7 participants with the purpose of providing a more comprehensive overview of the experiences of people living (seasonally) in different cities in both Mexico and Canada. Given the time limitations and scope of this research, I chose the sample according to participant's availability, ensuring I covered migration to and from different cities.

It is important to note that all participants were recruited under the same inclusion criteria, meaning that all shared the same characteristics of age, citizenship, length of stay in Mexico, and type of migratory movement (pendular). They all were retired (even if this was not an inclusion requirement). There was only one participant who contacted me stating she was interested in participating in the project, even though she did not consider herself a snowbird; among her reasons, she stated that even though she met the inclusion criteria, her stays in Mexico were not during the winter months but rather in different months during the year. I decided to interview her even though indeed she did not match the definition of a snowbird, given that she does not go to Mexico during the winter time only, because she lived among the people who do "fit" the definition and could provide valuable information for the research.

The interview asked general demographic questions. The five women and two men interviewed ranged between 55 and 80 years old, four of them were married, two divorced and one widowed. Only one person makes the trip on her 
own, all of the others travel to Mexico with their spouses or current partners. However, the interviews were conducted individually, permitting to reflect each unique experience. All participants were White. Three reported being landed immigrants (from the U.S. and Western Europe). One participant had a middle school education, one had a high school education, four had a bachelor's degree, and one had a master's degree. All were retired. One reported having a part-time job in Mexico and Canada, four did volunteer work while in Mexico, one is looking to become an entrepreneur. Participant destinations included San Miguel de Allende (2), Paamul (2), Cancun (1), Puerto Vallarta (1), and Oaxaca City (1). Their Canadian provinces of origin are British Columbia (5) and Ontario (2).

Six participants own a residence in Canada; one rents. In Mexico, four of the participants rent a place to stay or eventually stay with friends, two own a residence, and one owns the lot where their RV is placed. Participants' range of years going back and forth between Mexico and Canada for extended periods of time (4-7 months) and have been going from 3 to 13 years. Some of them have missed only one year of travelling to Mexico, given health or familial issues. Only one participant has legal permanent residency in Mexico. She obtained it only to ease the access to the country or extend her stays in Mexico. However, the participant is not sure yet whether to stay permanently in Mexico: "I am worried that in my old age I will find it financially impossible to live in Canada and then I can live in Mexico". The other six participants enter Mexico with temporary status (tourists). Four of them will not apply for permanent residency as they plan to always come back to Canada; the two others are on their pathway to permanent residency. Paradoxically, two of the respondents who stated that they would not apply for 
permanent residency and who identify themselves as snowbirds and long-term tourists own a residence in Mexico.

The data of the two participants in Toronto were collected through a private interview, in person, at a public place (coffee shop). Participants outside of Toronto were individually interviewed by videoconference (Skype). I used an interview guide (Neuman \& Robson, 2018) that contained open-ended questions, having the opportunity to follow-up on themes that could enrich the research project. The interviews were about 45 to 90 minutes in length. The purpose of the interviews was to describe the participants' experiences in Mexico, the perception of themselves as snowbirds, the reasons to leave Canada and to choose the place to spend the winters, the knowledge of the language, politics and local news. These questions allowed measuring transnational practices that are also essential indicators of the (re)shaping of the snowbirds' identities and community building. Participants were given the option to skip any question if they did not feel comfortable answering.

The interviews were audio recorded and transcribed in full. I reviewed the interviews twice to understand, analyze and code the main themes that emerged. Given that the sample is not representative, I am not looking to make any generalization but to gain some insights from the participants to compare patterns between Canadian snowbirds in Mexico and previous studies made on snowbirds in Mexico or other parts of the world. Also, I wanted to give voice to the experiences of Canadian snowbirds going to Mexico, as no such research has been done before. 


\section{Chapter 4}

\section{Canadian snowbirds in Mexico: Transnational Life Experiences}

The interviews conducted with the seven participants provided different insights on how each one of them lived the experience of going back and forth between Mexico and Canada. While six of them share the same characteristics to be considered a snowbird, their particular experience differs depending on their previous and current contexts. One participant met the criteria to be a snowbird (according to the definition discussed in chapter 1) with the exception that she travels to Mexico during different times of the year (not only in the winter). However, she still shares the experience of temporary migration and provided information about the other, "real snowbirds".

In the following section, I will discuss some of the most relevant topics that emerged during the interviews. The six dimensions of transnationalism (Gustafson, 2008) will be analyzed throughout the different topics. It is important to highlight that not all of them are found in the discussion of each topic but rather throughout all of them.

\section{Not everyone likes to be a snowbird}

"They are old White persons who go to another country, to a warm place in the winter, they go away from the snow. I do not consider myself a snowbird, I am a person who has chosen to live in two countries, I am lucky"

(Phoebe, research participant)

The debate to find a definition of the term snowbird exists not only amongst scholars, but also amongst the people who are usually known or labelled as one of 
them. When participants were asked to provide their own definition of snowbird, some showed reluctance to being labelled as one. In contrast, some others accepted themselves as snowbirds; they nodded while smiling, affirming they were one of them. It is clear that the connotation of snowbird does not fit for all. Participants identified themselves with different adjectives or nouns that make them feel more comfortable. This is possibly related to the fact that the stereotype of the tourist does not have a positive connotation (Benson \& O'Reilly, 2009). Thus snowbirds want to place themselves outside this definition. One of the participants said he considered himself more a traveller than a tourist because travellers are supposed to be more interested in the local culture:

I conceive of myself not as tourist, but as a traveller. Travellers are supposed to be more interested in things that they are seeing, and tourists are just there enjoying the cocktail and the beach, whereas the travellers are more interested in the involvement in Mexican culture. On the other hand, through most definitions or criteria I would be a snowbird [...].

Similarly, another participant also referred to her preference to be immersed in the Mexican culture rather than just being a tourist. The word "gringo" came up as a symbol of someone who does not want to interact with the local community. Therefore, the term snowbird is related somehow to a lack of belonging to the local community:

I try not to have a gringo experience, I try not to make my life like gringos. I try to make my experience as intercultural as I can. The gringo experience is like the gringo bars. We have some gringo bars and people who visit these bars will never speak a word of Spanish. I do not know if they are nervous or 
they are not adventurous but they hang around in gringo bars that are designed for Canadians and Americans. The bars are often owned by Americans and Canadians, so customers go there to speak in English and to drink. I like to visit "el día de los muertos" ${ }^{4}$ celebrations because I really like them. I like to watch the "peregrinaciones" $[\ldots]$ I just see my neighbours in the evening drinking, and I say to them, are you going to parque ${ }^{6}$ Lazaro Cardenas to see the dancers? They all say no, no, no. I do not understand that because the culture is so interesting.

Desrosiers-Lauzon (2011) explains how snowbirds look for real ethnic experiences and not only for the touristic ones. They want to immerse themselves in a different culture and become part of it. When snowbirds return to home and their routine activities, they feel the need to come back to the place where they find authenticity.

Drawing from the above participants' statements and based on DesrosiersLauzon, three dimensions of transnationalism arise: mobility, identity and belonging, and cultural practices. They move because they want to find authenticity in a culture different from their own at the same time that they want to belong to it; therefore, they return every year to pursue that authenticity and live it. They do not want to be the other, the gringo, the tourist. They want to participate in the local celebrations as the locals do, to travel and to experience rather than sitting and drinking like a regular tourist. Finally, they want to participate in the culture of the

\footnotetext{
${ }^{4}$ Día de los Muertos or Day of the Death (in English) is a Mexican tradition to celebrate the life after the death of people's beloved ones.

${ }^{5}$ Peregrinación or pilgramage (in English) is Mexican religious tradition that brings pilgrims together to walk to the church. During the pilgrimage, people usually are praying or dancing prehispanic dances.

${ }^{6}$ Park
} 
receiving country by assisting to local traditions, speaking the language and mingling with the locals.

The use of the term snowbird is not seen negatively only because of the touristic perception. Another participant stated she does not like to call herself a snowbird given the military associations, "I don't like the term for the military connotations of the Canadian snowbird military plane shows", referring to the " 431 Air Demonstration Squadron comprised of the Canadian Air Forces members and National Defence Public Service employees" (Royal Canadian Air Force, 2018). The same participant also stated, "I prefer to see it more like what butterflies do which go back and forth seasonally". She asserted that she did not consider herself a snowbird first because it made her think only of Canadians going to Florida, an image she did not feel drawn toward. She defined herself as a seasonal tourist, observer and participant: "I would say, we are participants, we take part in the culture".

Because of the above, the identity dimension emerges again when participants decide to put boundaries on the definition by expressing not only who they are but also who they are not. Tajfel (1974), Tastsoglou (2001), BokserLiwerant (2002) and, Muir (2007) affirmed that identities do not only refer to the sameness of a social group, they also inform how one is different from the others (as cited in Gilkinson \& Sauvé, 2012).

Therefore, it can be said that there is a group of people that, although perceived as snowbirds from the outside, do not perceive themselves as such. They try to define the meaning of the term and to draw a clear line that differentiates them. The participant, who identified herself as not being a snowbird 
because she did not go to Mexico during the winter season said: "The word snowbird, I just don't feel like it fits me but I feel like, when I talk to my friends, I say, I live in Cancun, it's not like, I go to Canada, this back and forth thing". She added that there is a difference between snowbirds or temporary residents who are not part of the snowbird group and the community of residents. To differentiate them she calls them the owners and the renters. The owners are the ones who have a property, who are more established, who either live in Cancun permanently or rent the place to the snowbirds. The renters are the tourists who are the renters.

The participant said the renters are more likely to make a touristic life, they are not interested in the local life and have their own communities, while the owners are more settled with both the "expat community" and the locals. Most of the interviewees brought up the term expat when trying to find a definition of snowbird:

In Cancun, there is this group called, Cancun expats, it is a Facebook group and, they are very active. I have met a lot of very lovely people through that. So, what happens is that during the summer, right now, there is a group of maybe 20 people that kind of routinely get together and then the snowbirds happen from around of October right up to March, middle of April, you have the group, doubles and triples. They are the snowbirds, they all come in and they rent a place, and they bring their dogs. Then this smaller group that get on well is inundated by the snowbirds. And then the snowbirds, it's a mass exodus coming from April or May, or March or April, they are gone. They are the ones who live on the hotel zone, some of them are more adventurous and do this downtown "centro" thing, most of them come down as couples, 
some ladies that come regularly as well. I just don't see myself like that because these people, they don't have any interest in Cancun.

Some of the participants use this concept referring to a group to which they do not belong, some others to members of their community. Therefore, I delved more deeply into the topic to try to unravel the overlapping concepts. It is curious how the concept of expat came up during the interviews, but never the term (im)migrant. When asked how they defined an expat and what was the difference with an immigrant, they provided responses that range from immigration status, through the length of stay in the country and the decision of not renouncing previous citizenship, to taxation. Thus, one participant stated that expatriate "means someone who wasn't born in the country where they are residing". I asked her if that was not the same as an immigrant, she doubted and responded, "I think that the word immigrant sounds to me like I am there under full status, I am an immigrant, I immigrated. But for me that does not fully fit because I do not have my status, I travel as a tourist right now". I asked her then if she would become an immigrant when she moved permanently to Mexico (as during the interview she expressed her intention to become a permanent resident of Mexico and move on a permanent basis), to which she responded affirmatively.

Another participant indicated that an expatriate was someone who lived permanently in another country and added that they are mostly retired people who live full time or most of the year in another country (Mexico). He added that if someone lived there for some months only, they are not expats. Furthermore, he referred to people who married Mexicans and stayed in the country but continue to be Canadian citizens as having become expats, whereas an immigrant is someone 
who changes residence to a new country to work or start a business. He concluded that expats have their communities and do not mix with the locals as the immigrants do.

Drawing from O'Reilly's (1995) five-fold typology of lifestyle migrants, "expatriates move permanently; identify as living in the area; might own property; express intention of never returning" (as cited in Williams, King, Warnes, \& Patterson, 2000, p. 36). Moreover, Croucher (2012) states that the term expatriate is used to define the lifestyle migrants who live in "expat bubbles" (p. 7), meaning they maintain contact only with their homeland -socially, culturally, and politically — they live in their homogeneous communities of conationals, sometimes provoking tensions with the local communities. Furthermore, Leonard (2010) contends that this concept (expat) "is used in an exclusionary sense, to connote classed Western whiteness and middle-class professionalism" (as cited in Croucher, 2012, p. 4). When one of the participants was asked if she thought that the term expat was related to class, she said, "there is nothing classist in that because you still have people who are living really low income (amongst expats) and it does not matter, it's not a classist thing". However, despite these considerations, Canadian expats still enjoy incomes and privileges often far in excess of locals. Thus, class-based discourses may be unintentionally reproduced amongst snowbirds as a result of these realities.

Lastly, the term expat was also related to taxation matters and citizenship. One participant pointed out that one can (legally) change their place of residence but not give up citizenship. He highlighted that the taxation structure for him might change given that he would no be longer residing in Canada but he would continue 
to be a Canadian Citizen. That being said, he would become an expat rather than an immigrant who is more likely searching not only to legally change residence, but also to probably become a citizen of the receiving country. The identity and belonging dimension, as well as the politics and legislation dimension, are reflected in this response. An expatriate does not renounce citizenship, they continue to be attached to their country of origin but live abroad under a different tax structure, whereas an immigrant would tend to assimilate to the host country.

Therefore, snowbird definitions continue to exist overlapping with travellers, tourists, participants and observers. What all of them have in common is that definitely, the weather is the main driver to make them leave Canada and make them look to the South to find a warmer climate in Mexico. One participant said, "snowbird is someone going south to avoid the snow", another stated: "as soon as it gets cold we flee the snow, fly south for the winter!".

They all agreed that their decision to spend winters in Mexico was a gradual, developmental, process, as stated by Bjelde and Sanders (2012). They start making short trips to the place where they will spend winters in the future, the length of stay increases with time until they decide to move there for full winters. Accordingly, participants stated that they did not decide overnight to go to Mexico during the winter, they planned it and prepared themselves. Most of them waited for their retirement so that they had the time and economic means to travel for more extended periods of time. In that way, one participant said, "We did a lot of vacations in Mexico, we had a timeshare and, then we got the house to the point, where I am retiring, and I am doing the back and forth". Deciding to travel to a specific place and to later migrate seasonally can take decades and even be 
generational. One of the participants, whose spouse's mother started going to San Miguel de Allende after being invited by other friends, said he decided to continue going regularly after several visits to his mother-in-law, and previous travels with different objectives such as education ("It is kind of funny because I first went to San Miguel de Allende in 1966, I went there for 2 days while on the way to Mexico City to work on a student community project"); leisure ("then, I came back to Mexico City with my wife in '73 and we went to San Miguel"); or social and family reasons ("And the real reason that we continued to go to San Miguel is that my mother-in-law was invited by some friends there in San Miguel so she stayed there every winter, every year since about ' 82 ').

Participants' contexts are different in Canada and in Mexico; therefore, their personal view of themselves and their communities change. Benson and O'Reilly (2009) contend that these types of migration, based on individual interests, move people to different places and to look for different experiences given their particular social capital. Notwithstanding these differences, participants shared the same characteristics that define a snowbird; however, individual experiences and perceptions of the self are different. While some participants rejected the term snowbird, others just accepted they were snowbirds and added that they even buy their "snowbird insurance" which is health insurance that it is explicitly sold to snowbirds.

Gilkinson and Sauvé (2012) explain how identities are not fixed but are continuously negotiated and even contested. Identities are relational, and thus are constructed by our own definition of the self and also ascribed by others. Therefore, if there is a discrepancy between what one thinks of oneself and how 
others perceive us, there is often a conflict of identity. Therefore, snowbirds' identities continue to be negotiated amongst themselves and people outside their communities —locals, tourists, and permanent residents- The snowbird concept is seen from different perspectives depending on the background of each person, their self-perceptions and the perception of the term itself.

\section{Cold ageing, warm youth}

"Winter is not only cold and snow, it's a state of mind"

(Hamelin, 1989, p. 1)

As confirmed by participants, snowbirds are escaping from cold winters; Mexico gives them the heat they cannot find back at home. Mexico is known worldwide for its extensive diversity of ecosystems that goes from deserts to tropical forests and mountains, to lakes and incredible beaches. According to the Mexican government, no matter where in the country, in general terms the weather is hot, warm and sunny all year long. High-altitude cities, like Mexico City, may have high temperatures during the day and colder nights. In contrast, in the coastal regions, the weather is semitropical with high temperatures that vary between $32^{\circ} \mathrm{C}$ to $35^{\circ} \mathrm{C}$ all year long. The average annual temperature is $19^{\circ} \mathrm{C}$ (PROMEXICO, 2016).

The influx of snowbirds differs considerably from the migratory movements of those (im)migrants who are fleeing from war, poverty or environmental issues. Weather and economic advantages are the main reasons for the Northern migrants to move, on a seasonal basis, to countries with warmer climates (King et. al, 2000 \& Helset et al., 2004; as cited in Gustafson, 2008), as in the case of Mexico. Accordingly, participants confirmed that their motives were to move to a place 
where they could enjoy higher temperatures that allow them to perform outdoor activities and improve their health and lifestyle. This means they would be able to socialize and continue the activities they would do in Canada if the weather were not extremely cold, as it is during the winter in their Northern places of residence.

Two themes continuously came together from the interviews: weather and ageing. During the wintertime, snowbirds do have enough time to perform numerous activities, but the weather does not allow them to participate in those due to their age and reduced cold endurance. Retirement provides them with the economic means and time to travel. Also, most of them related to Canada and its winters with boredom, whereas in Mexico their life was more joyful and active.

Canada is well known for its harsh winters, but also for having the infrastructure to make them bearable. During the interviews a participant confirmed the weather was her driver to leave Canada: she said "weather, absolutely weather". I then suggested that Canada provided her all the means to survive winters, to which she responded, "as you get older your bones feel it, and so that is a good reason why I feel younger, and I am active during the winter months", in Mexico. Similarly, another participant also referred to aging, weather and the possibility to keep themselves more active, "my husband is 75 and I'm 70, and we don't like winter, we don't like skiing anymore, we feel the cold more, so going down to Mexico we have been involved in the local community". Winter sports are no longer attractive; participants stated they preferred to go to the beach or sit in the "jardín"7

\footnotetext{
${ }^{7}$ Garden
} 
While the cold weather in Canada does not allow snowbirds to perform specific activities, the warm weather in Mexico allows an active pace of life. Participants related how they were involved in different activities while in Mexico. They are part of art colectivos ${ }^{8}$, volunteering organizations, sports teams, and social groups. McHugh (2000) argues that certain places empower people and provide more accepted images of ageing. In that sense, the life experiences of the participants of this study proved McHugh's theory. Even if all participants were retired, they continue performing activities in Mexico, sometimes the same ones they did before their retirement but with lesser work stress. Horn, Schweppe and Um (2013) defined transnational ageing as the "processes of organizing, shaping, and coping with life in old age in contexts which are no longer limited to the frame of a single nation-state" (p. 7). On this basis, snowbirds turn to a country where the context is different and allows them to have a better lifestyle. Therefore, weather and ageing boost snowbirds' mobility to Mexico that provides them with what they lack back at home, and also has the neccesary means to maintain their relations with family and friends back home during the winter time. It is important for them to keep this contact to reintegrate in their regular homes and lives once they are back in Canada in spring or summer.

Moreover, the weather in Mexico increases participants' social networks given that they engage in sports and other social activities. One participant relates how she can play volleyball on the beach with people of her age. Participants extend their productive life and continue working on what they like without taking

\footnotetext{
${ }^{8}$ Group of artists with shared social or political interests that work on common projects to achieve their group goals through art.
} 
into account work or time constraints. Another participant works part-time in a theatre in Puerto Vallarta, selling tickets and answering clients' inquiries, and she spends time with her work colleagues. Another interviewee is part of a ceramic "colectivo" in Oaxaca City, helping them with translations, editing, and curatorial work. She is also part of a horticulture project. Another participant made a bicycle ride from Toronto to San Miguel de Allende and fundraised 25,000 CAD for a Mexican-Canadian organization (Amistad Canada) that runs charity projects for the Mexican community. These seasonal migrations have reinforced their social belonging through the building of relationships and participation in projects.

Furthermore, the transnational economic dimension is reflected in the economic exchange through fundraising, donations and even the purchase of handicrafts for their homes in Canada. In contrast, all these activities strengthen their relationship with their ethnic community, as most of the activities are shared with other fellow Canadians or Americans with whom they speak English and build communities that allow them to create a "home-away-from-home" (Lardiés-Bosque et al., 2016, p. 829).

Finally, it is not easy to unravel the entanglement behind age, retirement and weather. What is true is that snowbirds' stays in Mexico made them feel younger and more productive: "I feel a lot younger, and I am active during the winter months", a participant said. Going to a place with warmer weather is not only about the heat but also about being able to go out, to socialize and to continue being productive. This confirms what Horn and his colleagues stated about transnationalism as a strategy to cope with ageing. 


\section{Exotic but familiar}

"I love that San Miguel is a heritage site, it is a 17th-century village flavour"

(Michael, research participant)

According to Coates et al. (2002), one of the main reasons for Canadian snowbirds to make their way down to Mexico rather than the U.S. is the downward trend of the Canadian dollar compared to the U.S. dollar. He also pointed out that other factors are the improvement in the Mexican transportation infrastructure and the increasing interest in Mexican culture. Although responses from participants coincided somewhat with the reasons cited by Coates and his colleagues in reference to culture, other motivations that made them go to Mexico were the proximity and accessibility to similar products and services as those offered in Canada. Mexico is a country with hundreds of years of aboriginal and colonial history and traditions, different traditional foods, and diversity in natural environments, all within reach. Mexico is diverse enough to be attractive but still similar to Canada in the provision of services and products, with the advantage of being economically more accessible.

Participants expressed the economic advantage of the Canadian dollar against the Mexican peso. Statements such as "You have good value for your money down there" and, "the cuisine is outstanding, and you can have a threecourse meal for well under 12 dollars (Canadian)" were amongst the most recurrent answers for their decision to go to Mexico. Snowbirds use transnational strategies to cope with different difficulties that can be faced in Canada after retirement. The Coates et al. (2002) study found that snowbirds from Canada come from different economic backgrounds and classes, and therefore, despite the 
limited incomes of some, their funds are more than enough to have a comfortable life in Mexico.

Furthermore, participants have made previous trips to other countries before going every year to Mexico. These travels allowed them to make a more informed decision and comparisons with other places where they could probably spend the winter. Participants stated they chose Mexico because compared with other places where they travelled before, such as China, India, Brazil, Cuba and even the U.S., Mexico is closer to Canada, it has accessible flights, the language is not that difficult to learn, it is not expensive, the food is good, and the culture is fascinating. Often, they knew people already living there and, communication technology such wi-fi mobile phone services were of high quality and very accessible. A participant complained about how poor wi-fi services are in Cuba; in contrast, "Mexican cell phone plans are the best in the world", she said. The easy access to transportation, technology and services in Mexico allow for mobility and helps to maintain their Canadian social networks. All the participants said they kept in contact with family and friends back in Canada through telephone and video conference. Likewise, Vertovec (2004), in his study "Cheap calls: the social glue of migrant transnationalism", explains that technological improvement has contributed to strengthening transnational social ties.

In regards to health care, Northcott and Petruik's (2011) research on the mobility of elderly Canadians suggests that snowbirds' seasonal migration lasts up to 6 months for fear of losing their provincial health care. In contrast, studies by Coates et al. (2002) have shown that Mexico becomes a medical tourism destination where treatments are much cheaper than in the U.S. and Canada with 
good results for the patients. Participants explained that one of the reasons to choose Mexico for staying for prolonged periods of time is the good health care services provided there. One of the interviewees said, "we've had great experiences with Mexican health care. In fact, outstanding care!". While the research by Northcott and Petruik indicates that some snowbirds return to Canada to keep their Medicare, my participants did not show their concern for that aspect at all.

Furthermore, participants reported their appreciation of Mexican culinary delights ("food is another reason for going there, the cuisine is outstanding", "I love Mexican food"); archeological sites ("we went around all the archaeological sites and travelled a lot in Mexico"); surprisingly, even security ("I feel safe there, my husband, he agrees, he feels very comfortable in Cancun"); and in sum, Mexico as a country of contrasts:

When I first toured Mexico, I just enjoyed the country very much, I liked the culture, I loved the people, it is a beautiful country, lovely diverse vacation in Mexico. Also, it is interesting the struggle that Mexico faces, developed Mexico and undeveloped Mexico living side by side.

Mexico and its politics could be described as exotic as well. After the independence of Mexico at the beginning of the 19th century, there was still much influence from the Spanish settlers in the country's politics. In the 1840s, the Mexican-American War led to the loss of a large part of the national territory. These two events in Mexican history gave rise to fears of foreign intervention in the country, prompting the drafting of article 87 of the legislation that allowed the president to expel foreign nationals who intervened in national affairs. This article 
laid the foundations for drafting article 33 included in the Mexican Constitution enacted in 1857 (Carbonell, 2006). Article 33 states that foreign nationals are not permitted to participate in national political affairs; to do so would would result in deportation (Constitución Política de los Estados Unidos Mexicanos, 2017). Therefore, no foreign individual, snowbirds included, is allowed to participate in the politics of the country. Mexican citizens are supposed to be the only ones with the right not only to vote but to participate in activism and any political manifestation.

In light of the above, some of the participants expressed interest in Mexican politics, even though they knew they could not participate in it. They wanted to know how the country was going to be run if some political tensions arose; they were also concerned about corruption and the well-being of their Mexican communities. Some of them followed the election in July 2018 and expressed their hope for a better government in Mexico. One participant said, "it is very interesting to see that Mexico goes to a more progressive president than in the U.S. and Canada, well not Canada but Ontario, and the Trump phenomenon, is just amazing".

Another participant recounted how she made photo journalism during a protest in Mexico. She remembered how she ran away from the police and mingled among the locals to go unnoticed. She added, "I went to Chiapas to meet SubComandante $\operatorname{Marcos}^{9}$, so I went up into the mountains to meet him, and I found it very interesting". Chiapas is one of her favourites states in Mexico, but she cannot

\footnotetext{
${ }^{9}$ Subcomandante Marcos was the leader of the Ejército Zapatista de Liberación Nacional (Zapatista Army of National Liberation) that emerged in Chiapas, Mexico in 1994. He advocated for the Mexican indigenous rights and claimed a better governance for Mexico. He was known for being very controversial.
} 
live there due to health issues: "Chiapas is too cold but the place is beautiful, and the people are very kind", she said.

Even though participants openly interested in politics cannot show their activism, they do it in particular ways such as through art, as one of the participants stated. Also, most of the participants who showed an interest in politics expressed their hope for a better government for the Mexican people with the newly elected leftist president. In contrast, some other participants said they are aware of Mexican politics, but they do not get involved, as they want to be law-abiding in order to not get in trouble, and that whoever rules the country, they cannot change it. Therefore, they prefer to remain silent as a popular Mexican saying states: "calladito te ves más bonito", which means, "when you are quiet, you look better", similar to the English expression "silence is golden".

Mexico is a country of contrasts that appeals to people from all over the world, snowbirds included. From traditional food to politics, it is a country exotic enough to be attractive but still keeping enough similarity with the way of living of North America. The mobility of snowbirds is shaped by Mexico's accessibility that allows them to maintain contact with their homeland not only by communicating with their family and friends back in Canada but also by having the opportunity to acquire goods and services with the "Canadian touch". Furthermore, the snowbirds find different ways to engage with the local politics through arts, journalism, and their awareness and hope for the country that hosts them every year. Politics, culture and mobility converge during their daily lives in Mexico, and in Canada when they bring back home all of the above through pottery bought from a Mexican 
artisan, photos shared with their family members, and their opinion and discussions with their friends or relatives back in Canada.

\section{Do you speak Spanish? -“Un poquito”10}

"The limits of my language mean the limits of my world" (Wittgenstein, 2010, p. 74)

In regards to language, all participants stated they don't speak Spanish fluently. Most of them said they speak "un poquito". According to Lardiés-Bosque et al.'s (2016) research, language barriers are strengthened amongst retired migrants given that they are not in a work environment that urges them to learn or improve their language skills. As a consequence, snowbirds tend to flock together like birds, to maintain themselves in a safe space where they can communicate amongst each other. Reliance on mainly English-speaking social circles and the maintenance of close family ties in Canda further reduces the capacity to fully integrate into Mexican society (Lardiés-Bosque et al., 2016).

Some participants explain how language barriers block their ability to develop a personal bond:

No, we do not have a Mexican community of friends, other than the people that live in the communities that we support, and it is just volunteering, and again the language issue, we are more in service to them, not as friends, if I could say that.

Furthermore, language barriers along with other factors such economic ones, lead to the search for a community of Canadians or Americans who share the same language and economic level:

\footnotetext{
${ }^{10}$ A little bit
} 
I have Mexican girlfriends and some of them speak very little English so that can be hard for me. It is fun to go to music gigs with them or cultural activities. Dinner is hard though as they have limited finances and I don't have enough money to pay for them most of the time.

As a result of the above, some snowbirds' interactions with members of the local community are reduced to basic conversations with those providing services to them. For instance, one participant stated, "I have communication skills (in Spanish) that are topic based with my maid". Another participant describes her interactions with people when she speaks Spanish:

My Spanish is not perfect, but I can talk to people. "Vendedores" ${ }^{\text {"11 }}$ on the beach love to chat and they have patience. The "meseros"12 like to chat too and, yes a lot of people stop and talk. I can manage these social activities in Spanish. I like to speak in Spanish, if I go to restaurants, I ask: "Quiero una mesa para dos personas a las ocho, por fa"'13 and then, if they answer me in English I ask if there is something wrong with my Spanish? No, we want to practice our English.

In the study conducted on snowbirds from Northern Europe in Spain; Williams, King, Warnes and Patterson (2000) explain how services and interactions occur mostly in English, given that the local authorities and people, in general, can speak the language. Similarly, snowbirds in Mexico make some attempts to build a relationship with locals. Some Canadian snowbirds have had the opportunity to meet and socialize with Mexicans who have higher levels of education, and

\footnotetext{
${ }^{11}$ Peddlers

${ }^{12}$ Servers

${ }^{13} \mathrm{~A}$ table for two, please
} 
therefore, speak English. One of my research participants said: "they (Mexican friends) speak Zapotec ${ }^{14}$, Spanish and English. I do communicate with them in English. That's unfortunate, I really want to change that $[\ldots] "$. Other Mexicans speak English, not because they had access to a high-level education, but because they need to succeed economically. They find ways to learn the language or at least some of its skills: "I admire the people there, we have a fellow who built our palapa, he is amazing, because Mayan ${ }^{15}$ was his first language then, of course, Spanish and, now English. He can't read or write and yet he speaks three languages", a participant stated.

From the above, the social mixing between snowbirds and the local population becomes complex. Different locations in Mexico receive snowbirds from different locations in Canada with various social, economic, ethnic and other sociocultural characteristics. Besides, Mexican society is also made of a mosaic of indigenous and colonial history. These two different cultures, with diverse demographic compositions and language barriers, result in a "pleasurable and attractive social mixing" that also implies difficulties caused by "cultural misunderstandings, mistaken assumptions about national characteristics, and ethnic differences" (Coates et al., 2002, p. 443).

In the same vein, media can be used as a bridge to understand local contexts, but language barriers break that opportunity. Many snowbirds try to read Mexican newspapers. However, their understanding is limited so they end up reading, listening and watching media from Canada, similar to what European

\footnotetext{
${ }^{14}$ Mexican indigenous dialect

${ }^{15}$ Mexican indigenous dialect
} 
snowbirds do in Spain (Williams et al., 2000). When participants were asked whether or not they follow Mexican news, their responses were: "No, we don't, we watch Canadian TV. Again, our Spanish isn't good enough, however when I'm here every day I google Mexican news to see what's happening in the Riviera Maya $[\ldots] "$

Some others continue to read the Canadian press: "I do follow the Times columnist and the Vancouver Sun, a little bit". Moreover, they continue referring to their struggle with language: "I try to read in Spanish. I can read some papers because they all have the same format. To understand it in full, it is difficult for me". Someone else stated, "I read the news in English, but if I want to know what it is going on in Vallarta, I have to read it in Spanish on the newspaper's website. I do try to read in Spanish". Also, snowbirds get information from local newspapers published by other Canadians or Americans who speak the language and make their summaries and reinterpretations of the local media; and reissue it in English: "I don't watch Mexican news but we have two newspapers that we read, Playa Times and the Pelican Free Press"16 Similarly, a participant stated:

In San Miguel, they have a newspaper, which is bilingual. It is called "Atención", and it is a bilingual paper run by the library. It is a public library but it is privately organized by NGO. That's for the expats. The gringos read it, because it shows all the cultural events that are happening, it has articles about it. It has some opinions about national, Mexican issues. That's one English paper that probably most of the gringos in San Miguel read.

\footnotetext{
${ }^{16}$ The Playa Times and the Pelican Free Press are two newspapers published in the Mexican Caribbean zone known as Riviera Maya. Their target is the English-speaking community in the area.
} 
Moreover, as a consequence of not being able to access the news themselves due to language barriers, participants highlighted how they rely on their friends to understand the place they live in: "I don't read the news in Mexico, I just get the information from my friends". Someone else stated:

I was following the election but because of my language issue, I have to translate everything, and that was a pain so, I had to rely on some of my friends who are fluent in Spanish, and I would ask them: tell me about the election, who is running? What is their background?

For better or worse, technology has played a crucial role in hindering the learning process thanks to the accessibility of simultaneous translation software and applications available on mobile devices. Consequently, the need to learn Spanish has decreased over the years and, even when snowbirds spend considerable time of the year in Mexico, they do not become proficient, they rely more and more on technology: "I signed up to the Riviera Maya news, which is an email connector. I get four or five messages a day; it comes in my inbox". In fact, a participant indicated how she and her husband speak less Spanish now than years ago during their first visits to Mexico:

It is really sad because it has become too easy with phone and these speaking translator apps where you say it in English, turn the phone to the young person, or the man, or the woman, and it translates what you are looking for. Also, they have a laptop on the counter and they type in Google translate and show it to you. We speak less Spanish now that we did when we started going down there 25 years ago. It is technology, right? 
In contrast, social media has become an alternative way of getting information among snowbirds. The information obtained from the media that most of the participants consult is interpreted by their social groups. Participants developed other ways to keep themselves informed, and social media has played a significant role, given that it provides accessible language and perspectives of the country and their communities through their friends and relatives. Social media was the most recurrent way of accessing information, according to participants: "Mostly, if I want to know what is going on in Vallarta, then I read the newspapers and the press on the social media", "[...] also, in social media you can see what is going on in Vallarta". Another participant pointed out that she mostly consults Canadian news and added:

[...] But I also, if I see what my Mexican friend posts on her social media, I see her stories and I say, what? I will talk to her so that she can explain to me and, what I see is that her sources are so different from mine and then, we will have talks about where she lives and the violence issues that she sees versus the place where I live and what I see, there is a big difference. Furthermore, social media has played an essential role in developing new forms of communication beyond the Spanish language. One of the participants of this study relates that she has a kind of competition with her Mexican friends, on Facebook and Instagram. They post pictures and compete to see who uploaded the best ones. They are all involved in visual arts. Therefore they understand the visual language. Social media based on images, such as Instagram, has contributed to the communication amongst people who do not speak or write the same language but share the visual one. 
In general, all participants showed their interest in learning Spanish; however, they had not had given themselves the time to become proficient. One participant expressed: "the problem with any language is one that you get a certain level to communicate, don't take the next step to become more like a native speaker unless you try hard. I have noticed that". More than one said that they were lazy or that they decided to give themselves a break after their retirement; therefore, learning a new language implied an effort that they did not want to make for now. However, all participants showed their interest to learn in the future, but at an easy pace: "I am going to do a course at some point, and if it takes me four years to get some decent Spanish, I am ok with that". Williams and his colleagues (2000) suggested that such "linguistic laziness" (p. 135) is the result of having interactions mostly within their small communities of conationals, other English speakers and the locals' willingness to speak in English. Drawing from the above, snowbirds do not need to learn Spanish, as immigrants driven by economic factors or forced migration need to, in order to survive in the receiving country.

It can be seen from the above that four out of Gustafson's six transnational dimensions are depicted in the topic of language: identity and belonging; social structures and networks; cultural practices and institutions; and politics and legislation. First, identity and belonging are found in the negotiation with others to speak one or other languages (spoken or visual), based on their needs. Snowbirds try to interact with locals in Spanish, even if they are not fluent, given that it makes them feel part of the community. During the interviews all participants would use, once in a while, a couple of words in Spanish, reflecting an identity shaped by their stays in Mexico. Second, the social networks and structures are built in response 
to their capacity to speak the local language. Therefore, the group of people with whom snowbirds get along is highly determined, most of the time, by language.

Also, language encourages more transnational practices through communication with family and friends back in Canada with whom they can discuss relevant topics in their mother tongue. Third, cultural practices and institutions go hand in hand with language; in the case of the participant who is involved in arts, it could be seen how language was not limited to Spanish but also extended to photography (visual language), and even to the creation of pottery. This art craft is often brought to Canada and becomes a form of expression that speaks about the experience of the snowbird in Mexico and about Mexican culture itself. And fourth, language proficiency allows becoming more involved in local politics, either to have more awareness of what is happening in the country or even participating in discussions and comparisons of how countries are run. As stated by Gustafson (2008), different transnational dimensions are reflected at different levels depending on the type of migration and the group of people moving between countries. Therefore, some transnational practices will be more frequent and tangible than others.

\section{Where is home?}

"One never reaches home, but where paths that have affinity for each other intersect the whole world looks like home, for a time."

(Hermann Hesse, 2013, p. 41)

From previous sections, it may be argued that participants live "in-between" Mexico and Canada, taking the best from both worlds. However, that fact raises another question: where is home for them? According to Lardiés-Bosque et al.'s 
(2016) study on American retirees in Mexico, their individual and collective identities flow between both countries. While maintaining the culture, language and social groups from the home country, retirees also develop identification with Mexico, and even though they were not fully integrated into the country, LardiésBosque and his colleagues' interviewees 'claimed to be as much 'at home' in Mexico as in the USA" (Lardiés-Bosque et al., 2016, p. 826). Similarly, Canadian snowbirds who participated in this study stated that Mexico was their second home, they highlighted that even though they thought their home was Canada, mostly because of the time spent there and their family relationships, Mexico still felt like home. One participant stated that he continues going to the same place every year because he sees people that he already know and that makes feel him more at home. Participants' responses varied from stating that their home was in Canada to saying that both places were home. One participant said he was homeless given the fact that he goes back and forth between the two countries, and that he has made various trips to different countries at different stages of his life.

According to Krumme (2004), sometimes, the sense of attachment and belonging to a country "cannot be classified as 'either-or' but as 'both-and" (as cited in Balkir \& Böcker, 2015, p. 127). Some participants refer to both countries as their home: "Well, we call Mexico our second home, but for sure, yes, Canada is still our home". Another participant stated:

Both, you know, I consider both my home. My American friend just wrote to me from California and said, "I can't wait to go home", so a lot of us consider 
Vallarta our home. Definitely, anywhere in Mexico could be home, I love a lot of things there.

Çaglar pointed out that people who live transnational lives develop "complex attachments and multiple allegiances to issues, peoples, places, and traditions beyond the boundaries of their resident nation-states" (as cited in Vertovec, 2002, p. 580). Therefore, it can be said that participants also developed multiple attachments that cannot be limited to their own country or city but rather expand to their winter home.

In contrast, while the majority of the participants revealed that they had a strong attachment to Mexico, some still highlighted that their sense of home was in Canada. Some scholars (Grant, 2007; Walters, Phythian, and Anisef 2007) have agreed that amongst the factors that shape identity and belonging, the time spent in a place is one of the most important (as cited in Gilkinson \& Sauvé, 2012). This was confirmed by participants: "well, I lived in Canada for 30 years, you know, and my thinking, I guess, is probably more Canadian". Similarly, a participant stated: "Yes, our home is Canada, because we spend more time here". Thus, time spent in a place makes one feel more identified with places and people; it feels more comfortable, and it makes people feel at home. In the same vein, Gilkinson and Sauvé (2012) explained how immigrants, at different stages of their immigration process, develop a sense of belonging and identification not only with the receiving country, but specifically with a region or neighbourhood, as a result of the time they spend in such places and the positive experiences they get from the hosting society in such neighbourhoods. Therefore, that was the reason for which some participants had a more regional than national attachment, given that they usually 
referred to their second home not as Mexico but as the city where they go and spend most of their time in Mexico; this regional attachment is similarly reflected when they refer to their home in Canada. For instance, a participant stated:

My home, I feel, is Cancun. The physical structure of a home, I got that in Cancun. But when I think of "hooome" it is the city of Victoria, because my husband and I have moved around so much. It is a sense of feeling when I walk around Victoria. It is not a physical place there. Because I was born and raised in Victoria. But every time I am landing in Cancun, I am really happy.

Other participants also referred to their travels to specific cities in Mexico where they have developed a community, and they know how the places work, where to find what they need, and so on. In sum, they understand their surroundings.

Moreover, participants' sense of home was also defined by their familial ties in Canada. Thus, family ties motivate people to continue doing seasonal migrations instead of settling in one place or the other. Gustafson (2008) pointed out that social and emotional ties to the family boost this type of migration. In this regards, participants stated: "we are a very close family. We are living now on the lake. Every week our children come home, and our children and everybody and we could not do that if we live permanently in a foreign country". Other participants also expressed similar thoughts and feelings about going back home (Canada) to spend time with their parents, children and grandchildren. It can be said, then, that their temporary mobility is highly related to their emotional ties. 
In conclusion, participants were more likely to refer to Canada or the city where they grew up as "home". This can be linked to the time they spent there and the social networks they have built. Also, while some others refer to Mexico as home, it is mostly referred to as the "second home", the adopted one. Attachment and belonging to Mexico or its regions is also related to the experiences lived in one or another place which is directly linked to the time spent in a place of residence. From the above, we can say that snowbirds continue to be trapped in the "in-betweenness", where the sense of home remains blurry. 


\section{Concluding Remarks}

Snowbirds' seasonal migration is a relatively a new phenomenon that is gaining more and more importance as its numbers expand due to the baby boom impact and the increase of the ageing population. As stated by Katz (2005), ageing people are making decisions on how and where they want to live, new places of residence where their identities will be reshaped. Snowbirds have been coming to Mexico for no more than 30 years, and it seems that their presence has not drawn much scholarly attention, as little research has been conducted on their migration to Mexico. As stated by Northcott and Petruik (2011): "Apparently, the seasonal migration of elderly Canadian snowbirds to southern destinations remains a greatly underestimated and understudied phenomenon" (p. 317). However, it is important to begin addressing the gap and encouraging more research on the topic.

Through this work, it was found that not all Canadian snowbirds in Mexico prefer to be labelled as such. There are some divided opinions as to what it means to be a snowbird, and there exists a negative perspective on snowbirds as Canadians fleeing winter but not getting involved with local communities, culture to which they 'fly'. Still others have embrace the term 'snowbird' despite its negative connotations.

Furthermore, it was confirmed that extremely cold winters are the first factor

that influences snowbirds to move to a warmer place. However, this is not the only reason. Once in Mexico, snowbirds realize that they can perform activities there that it would have been difficult to continue doing in Canada, either because of the weather, or because they are retired and their productive life seemed to have reached an end. Also, their social networks are considerably reduced given that 
they are not in a work environment, or that their friends perform different activities with their families. While in Mexico, they continue to do activities that extend their productivity, making them feel younger than in Canada.

Moreover, in Mexico they can find all the products and services offered in Canada at lower costs, allowing their retirement and savings to go much further. They can enjoy a better lifestyle and try new different culinary, cultural and social experiences that differ from Canada, but that are still familiar to them. The two countries are relatively close, and it is easy to access flights back to Canada at affordable prices. Also, it is easy to find the products and services offered in Canada, and most of the people in Mexico can communicate in English. That being said, it is not difficult to adapt to the place and to enjoy the advantages of going to Mexico during some months of the year.

Even though language is a barrier mentioned by all participants, the access to information through social media, technology and local people wishing to learn English to improve their job opportunities, makes their everyday life easier. They have developed alternative methods of communication that allow them to enjoy their stays in Mexico. However, due to language barriers, the snowbird community tends to flock to other English speakers, hindering their mixing with the local community.

Snowbirds have developed attachments to both places, Mexico and Canada, and also to specific regions in both countries. They find identification in both places and feel compelled to return to each place for different reasons. While one place provides them with warm weather, an active social life and a more 
attractive lifestyle, the other remains important because of their family ties, time spent there and the memories they have from the past.

Also, Mexico offers a variety of towns and cities where snowbirds can establish themselves for the winter season: from warm, artsy and colonial towns like San Miguel de Allende or Oaxaca; to small, isolated beach towns with an "easy" way of living, such as Paamul; through larger beach cities, such as Cancun and Puerto Vallarta. Thus, people with different backgrounds and various interests will go to different placea where the seasonal migration experience is entirely different for everyone.

Furthermore, snowbirds make a belated transnational life while discovering the best of two lifestyles. They develop a dual loyalty maintaining their roots and families in their homeland, taking the best from one side to the other, taking advantage of technologies, food or weather as convenient. They discover new societies and sometimes integrate into totally different groups that they never imagined could be part of their lives. They build new communities and give hope to others while volunteering in a developing community.

As suggested by Balkir and Böcker (2015), this social phenomenon goes beyond the dichotomy between permanent and seasonal migration. Different factors such as health, economy, family issues and accessibility to various services (internet, banking, health, among others) are essential to deciding to move permanently to a new country or to maintain a pendular migration. However, these decisions are planned and developmental, confirming that migration is an ongoing process as discussed by Glick-Schiller et al. (as cited in Lizárraga et al., 2015), rather than an overnight decision and one-time committment. 
This initial attempt to better understand the social phenomenon of Canadian snowbirds in Mexico was analyzed through the six transnational dimensions proposed by Gustafson (2008). However, there are a myriad of lenses through which to analyze this group of people. A more elaborate study would involve surveying the experiences and the insights of Mexicans themselves as they adjust to the influx of foreign nationals. What do the Mexicans think about their shared lifestyle? Are the snowbirds improving or hindering their economic, social and cultural situation? Are retired people in Mexico able to have a less stressful life and enjoy the country or the city as much as Canadian snowbirds do? A more exhaustive study of the topic would include an analysis to the entire scope of this social phenomenon from the perspective of both Mexico and Canada.

There is still much to discover about snowbirds in Mexico. The intention of this study has been to provide an opening into an area ripe for further study and analysis by immigration scholars. Snowbirds have found an attractive way of life by moving back and forth between Canada and Mexico. Something about the "inbetweenness" of their annual pendular migration has altered not only their style of living but also their perceptions of the wider world and their sense of social belonging. They have two homes now, the one granted through accident of birth and the other consciously chosen. 


\section{References}

Bantman-Masum, Ė. (2013). Enjeux de la mobilité des Canadiens et Américains au Mexique : stratégies économiques des migrants et réponse des États. Autrepart, 67-68,(4), 87-101. doi:10.3917/autr.067.0087

Bantman-Masum, E. (2015). Lifestyle transmigration: Understanding a hypermobile minority in Mérida, Mexico. Journal of Latin American Geography, 14(1), 101-117.

Balkir, C., \& Böcker, A. (2015). Maintaining dual residences to manage risks in later life: A comparison of two groups of older migrants. In Transnational Aging (pp. 137-152). Routledge.

Benson, M., \& O'Reilly, K. (2009). Migration and the search for a better way of life: a critical exploration of lifestyle migration. The sociological review, 57(4), $608-625$.

Bjelde, K. E., \& Sanders, G. F. (2012). Change and continuity: Experiences of midwestern snowbirds. Journal of Applied Gerontology, 31(3), 314-335.

Bolzman, C., Fibbi, R., \& Vial, M. (2006). What to do after retirement? Elderly migrants and the question of return. Journal of ethnic and migration studies, 32(8), 1359-1375.

Bryman, A., Bell, E., \& Teevan, J. J. (2012). Social research methods. Don Mills, Ontario: Oxford University Press.

Cahnmann-Taylor, M. (2014). Living the (Im) Perfect American Sueño/[Dream]:

Adult Spanish Language Study in Mexico. Anthropology \& Education Quarterly, 45(4), 409-413. 
Carbonell, M. (2006). La xenofobia constitucionalizada. Revista de la Facultad de Derecho de México, 56(246), 189-204.

Casado-Diaz, M. (2012). Exploring the geographies of lifestyle mobility: Current and future fields of enquiry.

Coates, K. S., Healy, R., \& Morrison, W. R. (2002). Tracking the snowbirds: Seasonal migration from Canada to the U.S.A. and mexico. American Review of Canadian Studies, 32(3), 433-450. doi:10.1080/02722010209481670

Constitución Política de los Estados Unidos Mexicanos. (2017). Retrieved from: http://www.diputados.gob.mx/LeyesBiblio/pdf/1_150917.pdf

Croucher, S. (2009). Migrants of privilege: The political transnationalism of Americans in Mexico. Identities: Global Studies in Culture and Power, 16(4), 463-491.

Croucher, S. (2012). Privileged mobility in an age of globality. Societies, 2(1), 1-13.

Desrosiers-Lauzon, G. (2011). Florida's snowbirds: Spectacle, mobility, and community since 1945. McGill-Queen's University Press.

De Wenden, C. W. (2009). Immigration and globalisation. Refugee Watch Catalogue, 33 .

Edmonston, B., \& Lee, S. M. (2014). Residential mobility of elderly Canadians: trends and determinants. Canadian Journal on Aging/La Revue canadienne du vieillissement, 33(4), 378-399.

Everitt, J., \& Welsted, J. (1999). Way down yonder, down Mexico way: Tourists, snowbirds and expats in Mexico. Prairie Perspectives, 2, 179-189. Retrieved 
from $\quad$ http://pcag.uwinnipeg.ca/Prairie-Perspectives/PP-Vol02/everittwelsted.pdf

Gilkinson, T. E., \& Sauvé, G. (2012). Recent immigrants, earlier immigrants and the Canadian-born: Association with collective identities. In H. Bauder (Ed.), Immigration and settlement: Challenges, experiences, and opportunities (pp. 147-170). Toronto, Canada: Canadian Scholars' Press.

Gouvernement du Québec. (2016). Régie de l'assurance maladie. Retrieved from: http://www.ramq.gouv.qc.ca/SiteCollectionDocuments/citoyens/en/depliants/ depl-services-couverts-exterieur-quebec-en.pdf

Government of Alberta. (2017). Health coverage outside Canada. Retrieved from: http://www.health.alberta.ca/AHCIP/coverage-outside-Canada.html

Government of Canada. (2012). Canada's Health Care System. Retrieved from: https://www.canada.ca/en/health-canada/services/health-caresystem/reports-publications/health-care-system/canada.html

Government of Canada. (2017). Overview of Canadian Consular Services in Mexico. Retrieved from: http://www.canadainternational.gc.ca/mexicomexique/offices-bureaux/index.aspx?lang=eng

Government of Ontario. (2017). OHIP coverage while outside Canada. Retrieved from: https://www.ontario.ca/page/ohip-coverage-while-outside-canada

Gustafson, P. (2001). Retirement migration and transnational lifestyles. Ageing \& Society, 21(4), 371-394.

Gustafson, P. (2008). Transnationalism in retirement migration: the case of North European retirees in Spain. Ethnic and Racial Studies, 31(3), 451-475. 
Hamelin, Louis-Edmond. (1989). Changing our Views about Winter. Writings in Gerontology. Seniors and Winter Living. The National Advisory Council on Aging. Minister of Supplies and Services Canada, Ottawa.

Happel, S., Hogan, T., Choi, W. (2004, May). Snowbird households add \$1 billion to state's economy. AZB: Arizona Business, 51(5), 5.

Happel, S. K., \& Hogan, T. D. (2002). Counting snowbirds: The importance of and the problems with estimating seasonal populations. Population Research and Policy Review, 21(3), 227-240.

Harper, D. (2011). Choosing a qualitative research method. Qualitative Research Methods in Mental Health and Psychotherapy, 83-98.

Hayes, M. (2015). Introduction: the emerging lifestyle migration industry and geographies of transnationalism, mobility and displacement in Latin America. Journal of Latin American Geography, 14(1), 7-18.

Hesse, H. (2013). Demian. Retrieved from: https://www.msjkeeler.com/uploads/1/4/0/6/1406968/demian.pdf

Hogan, T. D., Steinnes, D. N. (1993). Elderly migration to the Sunbelt: Seasonal versus permanent. Journal of Applied Gerontology, 12, 246-260.

Horn, V., Schweppe, C., \& Um, S. G. (2013). Transnational aging-A young field of research. Transnational Social Review, 3(1), 7-10.

Itzigsohn, J., \& Saucedo, S. G. (2002). Immigrant Incorporation and Sociocultural Transnationalism. International migration review, 36(3), 766-798.

Katz, S. (2005). Spaces of age, snowbirds, and the gerontology of mobility: The elderscapes of Charlotte County, Florida. In S. Katz (Ed.), Cultural aging: Life course, lifestyle, and senior worlds. Peterborough: Broadview Press. 
Lardiés-Bosque, R., Guillén, J. C., \& Montes-de-Oca, V. (2016). Retirement migration and transnationalism in northern Mexico. Journal of Ethnic and Migration Studies, 42(5), 816-833.

Lizárraga, O., Mantecón, A., \& Huete, R. (2015). Transnationality and Social Integration within Lifestyle Migration. A comparative study of two cases in Mexico and Spain. Journal of Latin American Geography, 14(1), 139-159.

Longino Jr, C. F., Marshall, V. W., Mullins, L. C., \& Tucker, R. D. (1991). On the nesting of snowbirds: A question about seasonal and permanent migrants. Journal of Applied Gerontology, 10(2), 157-168.

McHugh, K. E. (2000). The "ageless self"? Emplacement of identities in sun belt retirement communities. Journal of Aging Studies, 14(1), 103-115.

Mings, R. C. (1997). Tracking 'snowbirds' in Australia: winter sun seekers in far north Queensland. Australian Geographical Studies, 35(2), 168-182.

Neuman, W. L., \& Robson, K. (2018). Basics of social research: Qualitative and quantitative approaches (Fourth Canadian ed.) Pearson Canada Inc.

Northcott, H. C., \& Petruik, C. R. (2011). The geographic mobility of elderly canadians. Canadian Journal on Aging/Revue Canadienne Du Vieillissement, 30(3), 311-322. doi:10.1017/S0714980811000262

OFX. (2017). Exchange rate charts. Retrieved from: https://www.ofx.com/enca/forex-news/

Onyx, J., \& Leonard, R. (2005). Australian grey nomads and American snowbirds: similarities and differences. Journal of Tourism Studies, 16(1), 61.

Palapa. (n.d.). In Oxford Living Dictionaries online. Retrieved from https://en.oxforddictionaries.com/definition/palapa 
Portes, A., Guarnizo, L. E., \& Landolt, P. (1999). The study of transnationalism: pitfalls and promise of an emergent research field. Ethnic and racial studies, 22(2), 217-237.

PROMEXICO. (2016). Geografía y Clima. Retrieved from: https://www.gob.mx/promexico/acciones-y-programas/geografia-y-clima

Province of British Columbia. (2017). Health and drug coverage. Retrieved from: https://www2.gov.bc.ca/gov/content/health/health-drug-coverage/msp/bcresidents/eligibility-and-enrolment/are-you-eligible

Province of Manitoba. (2017). Leaving Manitoba to Travel, Work, Study or Move. Retrieved from: https://www.gov.mb.ca/health/mhsip/leavingmanitoba.html\#4

Rodríguez, E., \& Cobo, S. (2012) Los canadienses en México: Una aproximación histórica y sociodemográfica a sus procesos de inmigración y de movilidad internacional reciente. Migration policy institute. Retrieved from http://www.politicamigratoria.gob.mx/work/models/SEGOB/Resource/1353/4 /images/Cobo_2012_canadienses_mpi.pdf

Rodríguez Chávez, E., \& Cobo Quintero, S.D. (2017). Los canadienses en México. Inmigración y movilidad internacional. Migraciones internacionales, 9(1), 942. Retrieved from http://www.scielo.org.mx/scielo.php?script=sci_arttext\&pid=S1665$89062017000100009 \&$ Ing $=e s \&$ tIng $=e s$

SAT. (2017). Qué impuesto pagan los extranjeros. Retrieved from: http://www.sat.gob.mx/english/Paginas/que_impuestos_pagan_los_extranjer os.aspx 
Satzewich, V., \& Wong, L. (Eds.). (2011). Transnational identities and practices in Canada. ubc Press.

Schafran, A., \& Monkkonen, P. (2011). Beyond Chapala and Cancún: Grappling with the impact of American migration to Mexico. Migraciones Internacionales, 6(2).

Schweppe, C., \& Horn, V. (2015). Introduction: Transnational Aging: Current Insights and Future Challenges. In Transnational Aging (pp. 13-28). Routledge.

Smith, S. K., \& House, M. (2006). Snowbirds, sunbirds, and stayers: seasonal migration of elderly adults in Florida. The Journals of Gerontology Series B: Psychological Sciences and Social Sciences, 61(5), S232-S239.

Snowbird. (n.d.). In Merriam-Webster Dictionary online. Retrieved from: https://www.merriam-webster.com/dictionary/snowbird

Vertovec, S. (2001). Transnationalism and identity. Journal of Ethnic and Migration Studies, 27(4), 573-582. doi:10.1080/13691830120090386.

Vertovec, S. (2004). Cheap calls: The social glue of migrant transnationalism. Global Networks, 4(2), 219-224. doi:10.1111/j.1471-0374.2004.00088.x

Weitz-Shapiro, R., \& Winters, M. S. (2008). Political participation and quality of life. Inter-American Development Bank.

Williams, A. M., King, R., Warnes, A., \& Patterson, G. (2000). Tourism and international retirement migration: new forms of an old relationship in southern Europe. Tourism Geographies, 2(1), 28-49. 
Witter, Y., Cela, E., \& Fokkema, T. (2015). Pendular Migration of the Older First Generations in Europe: Misconceptions and Nuances. In Transnational Aging (pp. 153-172). Routledge.

Wittgenstein, L. (2010). Tractatus Logico-Philosophicus. Ebook \#5740. Retrieved from: https://www.gutenberg.org/ebooks/5740 